\title{
Observation and Quantitation of Exocytosis from the Cell Body of a Fully Developed Neuron in Planorbis corneus
}

\author{
Guangyao Chen, Peter F. Gavin, Guoan Luo, and Andrew G. Ewing \\ Department of Chemistry, The Pennsylvania State University, University Park, Pennsylvania 16802
}

\begin{abstract}
We have discovered a neuronal system that releases neurotransmitter via exocytosis from the cell body. In the large dopamine cell of the pond snail Planorbis corneus, depolarization induces rhythmic release of dopamine from the cell body. When a stimulant is applied extracellularly or intracellularly in situ to the cell body, transient dopamine concentration packets that appear in a bursting pattern are observed. Dopamine release is calcium dependent and release is on the time scale expected for exocytosis (2 to 4 msec rise times). Quantitation of individual events reveals an average of $\mathbf{8 1 8 , 0 0 0}$ molecules per exocytotic event. As many as 89,000 individual exocytotic events have been observed following a single stimulation of one cell. Neurotransmitter exocytosis from the neuronal cell body appears to represent an alternative form of neurocommunication to synaptic transmission.
\end{abstract}

[Key words: dopamine, dopamine exocytosis, cell body, snail, Planorbis corneus, electrochemical methods, capillary electrophoresis]

The cell body of a neuron is generally not thought to be involved in calcium-dependent exocytosis of neurotransmitters. Exocytosis of neurotransmitters occurs at synaptic terminals where communication between neurons is across a synaptic cleft of nanometer dimensions (Heuser and Reese, 1977). Although communication between glial cells and neurons has been intensely investigated recently (Charles et al., 1991; Murphy et al., 1993; Mennerick and Zorumski, 1994; Nedergaard, 1994; Parpura et al., 1994), little is known concerning communication between the neuronal cell body and other cells in the nervous system.

The basic question toward understanding the role of the cell body in cell-to-cell communication is whether the cell body of a neuron can release neurotransmitters under physiological conditions or following chemical stimulation. Previous reports have shown that mammalian neurons release neurotransmitters from the somatodendritic region of the catecholamine system (Cheramy et al., 1981; Gauchy et al., 1987; Klitenick et al., 1992). Release of neurotransmitters from the cytoplasmic pool of neuronal cell bodies has also been reported (Johnson and Pilar,

\footnotetext{
Received May 9, 1995; revised July 12, 1995; accepted July 20, 1995.

This work was supported in part by Office of Naval Research, the National Science Foundation and the National Institutes of Health. We thank Prof. David Sulzer (Center for Neurobiology, Columbia University) for critical discussion and comments and Prof. R. Mark Wightman (Department of Chemistry, University of North Carolina) for the suggestion to plot the frequency of release events versus the cubed root of the amount released.

Correspondence should be addressed to Professor Andrew G. Ewing, Department of Chemistry, The Pennsylvania State University, 152 Davey Laboratory, University Park, PA 16802.

Copyright (C) 1995 Society for Neuroscience $0270-6474 / 95 / 157747-09 \$ 05.00 / 0$
}

1980; Suetake et al., 1981). Exocytosis of the hormones vasopressin and oxytocin from cell bodies of hypothalamic neurons has been demonstrated by a combination of immunocytochemistry and electron microscopy (Pow and Morris, 1989). This evidence suggests that the cell body of some neurons contains the necessary elements required for exocytosis.

Exocytosis of catecholamines from single adrenal cells (Leszczyszyn et al., 1990; Wightman et al., 1991; Chow et al., 1992; Zhou et al., 1994), from pheochromocytoma cells (Chen et al., 1994), serotonin from mast cells (Alvarez de Toledo et al., 1993), and insulin from pancreatic $\beta$-cells (Kennedy et al., 1993) has been monitored with electrochemical techniques. This recently developed method involves the use of small carbon fiber electrodes to monitor and quantitate catecholamines released from individual exocytotic events at the cell membrane. Dynamic measurements with unprecedented time resolution (Chow et al., 1992), sensitivity (Chen et al., 1994), and spatial resolution (Schroeder et al., 1994) have been used to define the exocytosis fusion pore, level of release from small vesicles, and zones of release at the cell surface, respectively. All these experiments have been carried out with hormonal cell model systems in culture. There have been to date no examples of monitoring vesicular exocytosis from synaptic-like vesicles from a neuron.

In this article, we demonstrate the use of electrochemical techniques to monitor exocytosis from an intact neuron in dissected Planorbis corneus. The large dopamine neuron on the left pedal ganglion of Planorbis has been characterized with fluorescence and spectrophotofluorimetric techniques, and is the only dopamine-containing neuron of the Planorbis system (Marsden and Kerkut, 1970; Pentreath et al., 1974; Loker et al., 1975; Osborne et al., 1975; Berry and Pentreath, 1978). This neuron has multiple monosynaptic connections with neurons in the visceral and left parietal ganglia, and no connections have been identified with cells in the left pedal ganglion (Berry and Cottrell; 1973, 1975, 1979; Berry et al., 1974; Pentreath et al., 1974; Berry and Pentreath, 1978; MacDonald and Berry, 1978). In addition, the cell body contains a large number of both light and dense cored vesicles (Berry et al., 1974; Pentreath et al., 1974; Pentreath and Berry, 1975; Berry and Pentreath, 1978). We demonstrate here that massive exocytosis occurs at the cell body of this neuron following extracellular and intracellular chemical stimulation, contrasting the common lore that all neuronal exocytosis activity occurs at the synaptic junction.

\section{Materials and Methods}

Electrodes and voltammetric procedures. Working electrodes were prepared from $10 \mu \mathrm{m}$ diameter carbon fibers sealed in glass capillaries (Kelly and Wightman, 1986). The sensing tip of the electrode was exposed by cleaving with a surgical blade. The reference electrode was a 
sodium-saturated calomel electrode (SSCE). Constant-potential amperometry and fast-scan voltammetry were performed with a commercial potentiostat (EI-400, Ensman Instrumentation, Bloomington, IN). The applied potential for amperometry was $700 \mathrm{mV}$. A scan rate of 300 V/sec cycled between $-500 \mathrm{mV}$ and $1000 \mathrm{mV}$, with a delay time of 10 msec between scans was used for fast-scan voltammetry. The output was connected to an A/D converter (Labmaster, Scientific Solutions, Solon, $\mathrm{OH}$ ) interfaced with an IBM personal computer.

Capillary electrophoresis experiments. Fused silica capillary (144 $\mu \mathrm{m}$ o.d.; $14 \mu \mathrm{m}$ i.d.) was obtained from Polymicro Technologies (Phoenix, AZ) and etched in $48 \%$ aqueous HF (Aldrich, Milwaukee, WI) prior to use. The injection end was etched to a tip by immersion in $48 \%$ aqueous HF for 25 min under positive pressure (100 psi) of helium. The detection end was etched for $20 \mathrm{~min}$ in $48 \%$ aqueous HF (at 80 psi) to provide a conical entrance for electrode placement. 'The capillary electrophoresis system used for these experiments was similar to that described elsewhere (Sloss and Ewing, 1993). Briefly, the system consisted of a buffer filled capillary suspended across two buffer reservoirs. A high potential $(0-30 \mathrm{kV})$ was applied at the injection end of the capillary and the detection end was held at ground potential. For exocytosis experiments, a Petri dish containing the dissected snail, bathed in snail Ringer, was placed on the stage of a stereomicroscope (Nikon Corporation, Tokyo, Japan). The injection end of the clectrophoresis capillary was removed from the buffer reservoir, attached to a micromanipulator and placed in the Petri dish. Both the stimulation pipette and electrophoresis capillary were micromanipulated near the cell. The stimulation pipette containing $1 \mathrm{M} \mathrm{KCl}$, was poised $20 \mu \mathrm{m}$ away from the cell, whereas the electrophoresis capillary was placed just above the cell. A $6 \mathrm{sec}$ stimulation (corresponding to $500 \mathrm{nl}$ ) was used to elicit exocytosis. Sampling of material by the electrophoresis capillary was accomplished by electromigration starting $4 \mathrm{sec}$ after stimulation with a duration of $30 \mathrm{sec}$. After injection of the plug of material $(1.0 \mathrm{nl})$, the electrophoresis capillary was returned to the buffer reservoir and a high potential $(25-30 \mathrm{kV})$ was applied to affect a separation. Detection was performed in the two electrode format. A $5 \mu \mathrm{m}$ carbon fiber microelectrode, with an exposed length of 500-700 $\mu \mathrm{m}$, was micromanipulated inside the detection end of the electrophoresis capillary and held at $+800 \mathrm{mV}$ versus $\mathrm{Ag} / \mathrm{AgCl}$ for all experiments. Faradaic currents were acquired with the aid of a Keithley Model 427 current amplifier (Cleveland, $\mathrm{OH})$ and collected with a System Gold interfaced with an IBM PS/2 computer (Beckman Instruments, Palo Alto, CA).

Cell procedures. Planorbis corneus were obtained from NASCO (Fort Atkinson, WI) and were maintained in aquaria at room temperature until used. The snails were dissected under a snail Ringer solution $(39.5 \mathrm{~mm}$ $\mathrm{NaCl}, 1.3 \mathrm{mM} \mathrm{KCl}, 4.5 \mathrm{mM} \mathrm{CaCl}_{2}, 1.5 \mathrm{mM} \mathrm{MgCl}_{2}$, and $6.9 \mathrm{mM} \mathrm{NaCO}_{3}$ ) adjusted to $\mathrm{pH} 7.4$. The physiological calcium levels are higher for invertebrate systems compared to mammalian systems. The dissection procedure and the identification of the dopamine containing neuron were described previously (Berry, 1972; Logan and Cottrell, 1975; Loker et al., 1975; Osborne et al., 1975; Lichtensteiger, 1979; Chien et al., 1988; Steiner and Felix, 1989). Snail shells were smashed before snails were pinned with the ventral side uppermost in a wax-filled Petri dish. The skin of the head part was cut open to reveal the brain. The ganglia ring was pinned at the connective tissue to the wax with $7-10$ pins to extend the brain and expose individual cells. The outer connective tissue surrounding the brain was transparent and the orange-colored neurons could be seen beneath using a binocular microscope ( $70 \times$ magnification). The outer connective tissue was removed from the surface of the pedal ganglion by a home-made fine pin with a 90 -degree hook. The dopaminc neuron is usually the largest cell (75-150 $\mu \mathrm{m}$ in diameter) in the left pedal ganglion and is easily identified by its specific location close to the statocyst (Marsden and Kerkut, 1970; Berry et al., 1974; Pentreath, et al., 1974; Loker et al., 1975; Osborne et al, 1975). Experiments were performed immediately after dissection.

The Petri dish containing the dissected snail was placed on the stage of a stereomicroscope (Nikon Corporation, Tokyo, Japan). A working electrode was positioned over the top of the cell body of the dopamine containing neuron with a three-dimensional micromanipulator Mertzhauser (Zeiss, Germany). The electrode was manipulated so that it lightly touched the center of the cell body. Release of dopamine from the cell body of the dopamine neuron was induced through short-duration (4 to $6 \mathrm{sec}$ ) local applications of $1 \mathrm{M} \mathrm{KCl}$ solution prepared in the snail Ringer solution (this corresponded to ejections of 87 to $131 \mathrm{nl}$ ). For calcium-dependent experiments, a calcium-free Ringer solution $\left(\mathrm{CaCl}_{2}\right.$ was replaced by $\mathrm{MgCl}_{2}$ ) was used as the cell medium, and stimulation solutions $(1 \mathrm{M} \mathrm{KCl})$ were prepared in the calcium-free Ringer, and high calcium $\left(50 \mathrm{mM} \mathrm{CaCl}_{2}\right)$ Ringer, respectively. For experiments using ionomycin, a $6 \mathrm{sec}(270 \mathrm{nl})$ local application of $200 \mu \mathrm{M}$ ionomycin was used. All stimulation solutions were delivered by glass micropipettes controlled by a two-channel pressure application device (Picospritzer, General Valve Corporation, Fairfield, NJ). Typical tip dimensions of micropipettes for extracellular stimulation were $10 \mu \mathrm{m}$. They were positioned with a micropositioner (Medical Systems Corporation, Greenvale, NY) to a desired distance (5 to $20 \mu \mathrm{m}$ ) from the cell body. For intracellular sodium stimulation experiments, micropipettes with tip diameters less than $1 \mu \mathrm{m}$ and ejection volumes of picolitres were used. All data were digitized and filtered with a $100 \mathrm{IHz}$ two-pole low-pass filter. Experiments were carried out at room temperature.

Data treatment. Transient current responses obtained in the amperometric mode were evaluated by locally developed peak-detection-integration software. Only transients with peak widths less than $40 \mathrm{msec}$ and larger than 4 msec and peak heights larger than twice the peak-to-peak noise (dependent on the experiment) were considered. These transients were integrated by a trapezoidal method with respect to time to determine the amount of charge in units of picocoulombs $(\mathrm{pC})$. The vesicle content was calculated by $N=Q / n F$, where $Q$ is the charge under each transient in coulombs, $\mathrm{n}$ is the number of electrons in the dopamine oxidation reaction, $\mathrm{F}$ is the Faraday constant $(96,485$ coulombs/mol) and $\mathrm{N}$ is the number of moles. Histograms of the frequency of release events versus the amount of neurotransmitter released were obtained by sorting current transients in different size groups. Background-subtracted voltammograms were obtained by subtracting the average of several background scans from multiple scans obtained during exocytosis. All reported values are given with the standard deviation (SD).

Reagents and drugs. Dopamine (DA), catechol, uric acid, dihydroxyphenylacetic acid (DOPAC), and 2-(N-morpholinoethanesulfonic acid (MES), were obtained from Sigma (St. Louis, MO) and were used as received. Dopamine solutions were deoxygenated for 20 min prior to experiments and a blank of nitrogen was then maintained over the solution. Ionomycin was purchased from ICN (Costa Mesa, CA) and was prepared in normal snail Ringer solution. All solutions were prepared with doubly distilled water. For capillary electrophoresis experiments, standard solutions were made as $10 \mathrm{~mm}$ stock solutions in $0.1 \mathrm{M}$ perchloric acid and diluted in snail Ringer ( $\mathrm{pH}=7.4$ ) prior to use. The separation buffer was $25 \mathrm{mM}$ MES adjusted to $\mathrm{pH}=5.7$ with solid $\mathrm{NaOH}$ and filtered with $0.2 \mu \mathrm{m}$ Nylon 66 membrane filters (Supelco, Bellefonte, PA).

\section{Results}

\section{Current transients are observed at the cell body following} chemical stimulation

Electrochemical current transients were detected in vivo at a carbon fiber electrode placed on the exposed cell body (Fig. 1A) of the large dopamine cell of Planorbis corneus following ccll stimulation with elevated potassium chloride (Fig. 1B). These current transients are also observed following intracellular stimulation with elevated sodium (vide infra) and are apparently the result of individual dopamine exocytotic events. These events have rise times typically between 2 and $4 \mathrm{msec}$ and an average basewidth of $14 \pm 0.8 \mathrm{msec}$ (Fig. $1 C$ from 13 cells and 12,324 transients), which is consistent with the time scale expected for exocytosis. In addition, the observed current transients are generally observed to occur in a bursting pattern, as shown in the expanded region of an experiment in Figure $1 D$. Since virtually all the dopamine released under the electrode will be oxidized at the electrode, we can quantitate the total amount of this neurotransmitter from each individual exocytotic event by integrating the current observed. A histogram showing the number of transients versus the amount of transmitter per event is shown in Figure $2 A$. In contrast to the commonly held belief that packaging of neurotransmitters in vesicles is invariant (Redman, 1990), it is clear that a fairly broad distribution of vesicle sizes is available for release from the Planorbis cell body. The charge measured for an average transient corresponds to $1.36 \mathrm{amol}$ of 
A

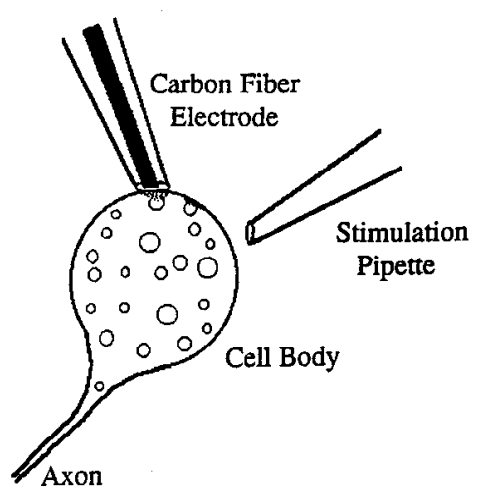

B

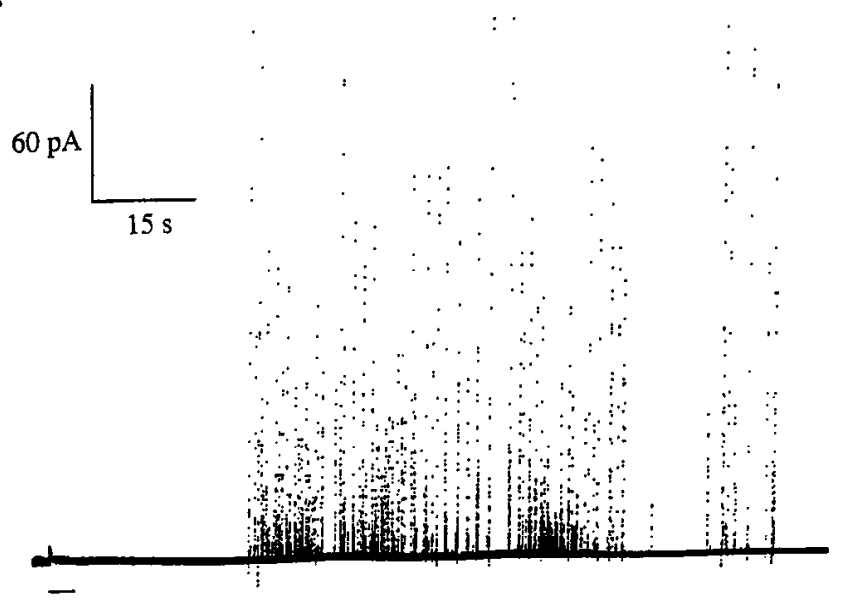

C

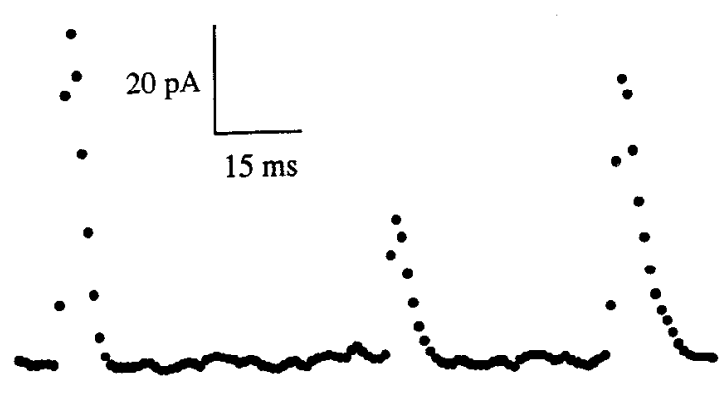

D

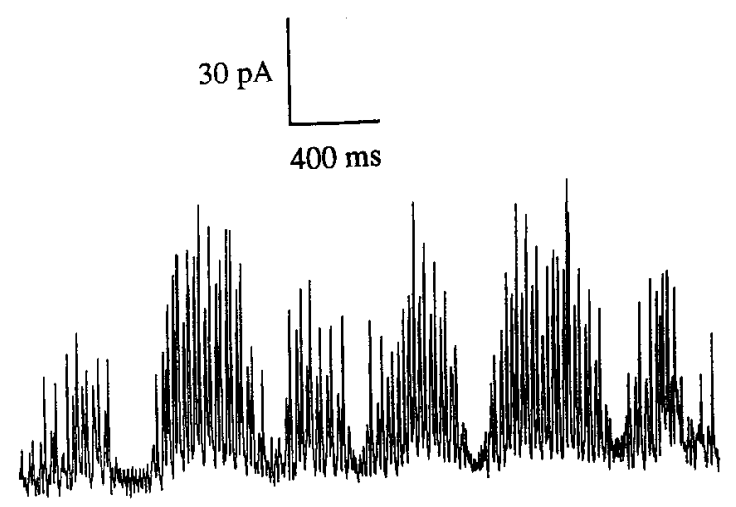

dopamine released per exocytotic event. The distribution of release transients might be the result of different vesicle sizes in the cell. A Gaussian distribution of vesicle radii has been observed for adrenal cells by electron microscopy (Coupland, 1968). As the amount of catecholamine is expected to vary directly with vesicle volume, a Gaussian distribution is expected if the frequency of release events is plotted versus the cubed root of the number of dopamine molecules measurcd from cach vesicle. This is shown in Figure $2 B$. The Gaussian shape of the major part of this histogram appears to indicate a distribution of vesicle sizes in the Planorbis cell similar to that observed in adrenal cells and is compelling evidence that the current transients observed are, indeed, representative of individual exocytotic events from the cell body. It is interesting to note that this distribution also shows a smaller Gaussian, with an average vesicle content approximately $4 \%$ that of the large Gaussian, possibly indicating two specific classes of dopamine vesicles in this cell. Variation in vesicle size has previously been observed in this cell by electron microscopy (Berry et al., 1974; Pentreath et al., 1974; Pentreath and Berry, 1975; Berry and Pentreath, 1978) and evidence for two specific compartments of dopamine vesicles has been obtained with capillary electrophoresis (Kristensen et al., 1994).

\section{Evidence that dopamine is released}

Identification of the released transmitter as dopamine has been carried out by comparing voltammograms for stimulated release (in this case, release was stimulated by intracellular injection of elevated sodium). The current transients observed after intracellular sodium stimulation are shown in Figure $3 A$ with the corresponding voltammogram in Figurc $3 B$. A voltammogram for dopamine released by reverse transport is shown for comparison in Figure $3 C$. These voltammograms have similar half wave potentials and voltammetric shape. The only other substances observed to have similar half wave potentials and voltammetric shape are epinephrine and norepinephrine. These substances are not detected in this cell (Powell and Cottrell, 1974; Osborne et al., 1975; Berry and Pentreath, 1978). Thus, it appears that the observed current transients are due to dopamine exocytosis from the cell body.

We have also used capillary electrophoresis with electrochemical detection (Mesaros et al., 1994) to identify the substance released following cell stimulation. An etched fused silica capillary was used to collect solution immediately outside the cell

\section{$\leftarrow$}

Figure 1. Dopamine current transients detected by carbon fiber disk electrodes following cellular stimulation. $A$, Schematic of a carbon fiber electrode placed on the top of the cell body of an in vivo Planorbis dopamine neuron and a stimulation pipette placed close to the cell body. $B$, An example of current transients recorded with the amperometric constant-voltage method. A large Planorbis dopamine cell (diameter about $100 \mu \mathrm{m}$ ) was stimulated with a $4 \mathrm{sec}$ potassium chloride $(1 \mathrm{M})$ pulse $(87 \mathrm{nl})$ delivered from a glass pipette that was placed about 15 $\mu \mathrm{m}$ from the cell body. The stimulation is shown by the horizontal bar below the trace. $C$. Examples of the expanded secretory events with base widths ranging from 4 to $40 \mathrm{msec}$ and an average width of 14 msec ( 13 cells and 12,324 transients). The typical releasing shape, fast increase, and gradual decrease, represents the kinectic process associated with the extrusion of neurotransmitter from a single vesicle into the extracellular space and its diffusion away from the cell body. Data points were acquired every $1.0 \mathrm{msec}$ and typical rise times were 2 to 4 msec. $D$, Bursting release events were observed in 24 out of 29 cells that showed release transients. The overall success rate for observation of current transients from cells sampled was approximately $50 \%$. 
A

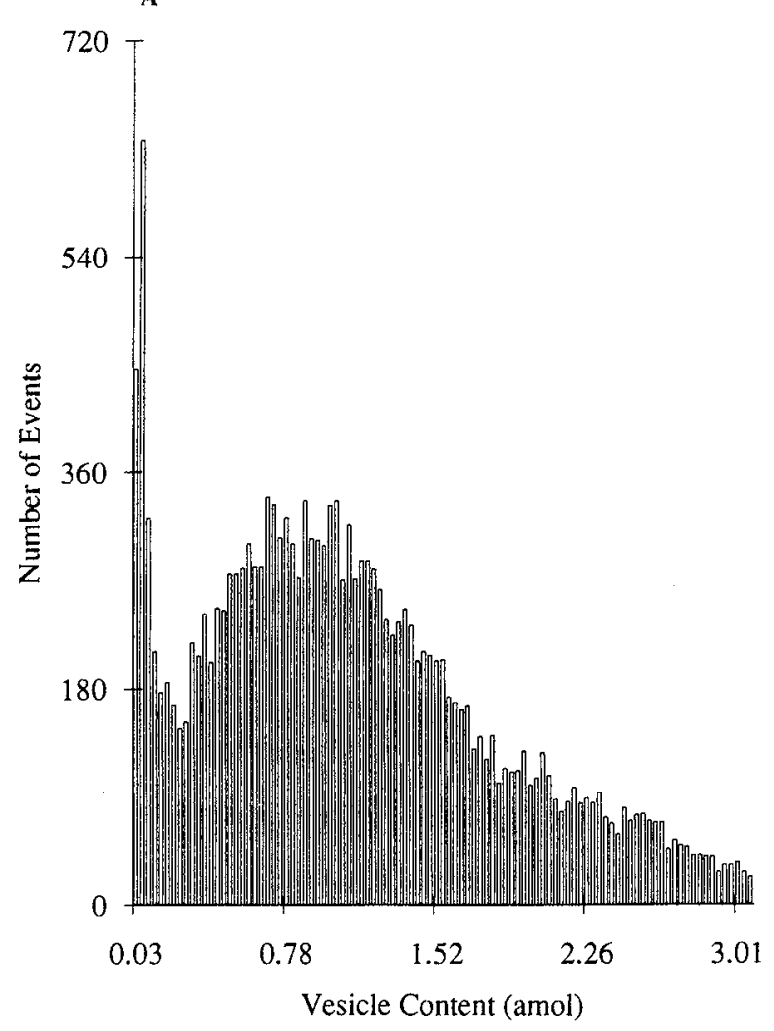

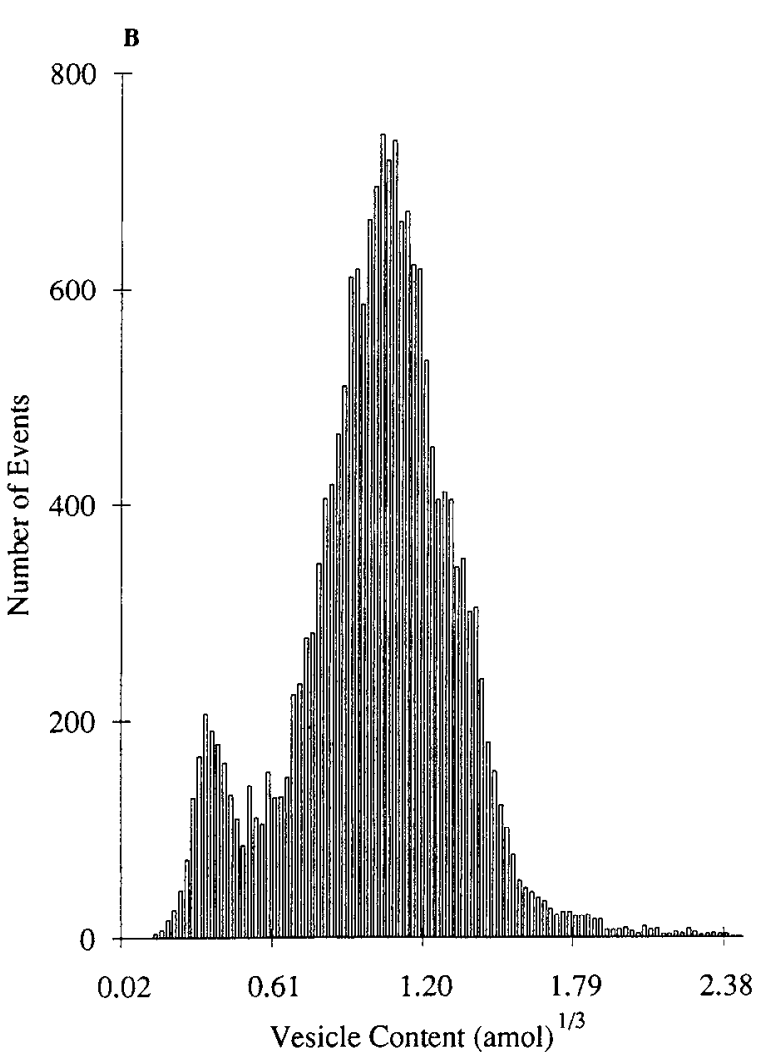

Figure 2. Histograms of the frequency of release events versus the amount of neurotransmitter released. $A$, Frequency versus attomoles of dopamine released ( 16 cells, 18,456 events). Only release events with base widths less than $40 \mathrm{msec}$ were considered. Wider transients, which contained less than $2 \%$ in total number and most of them appeared to contain contributions of more than one vesicle (appeared as doublets and shoulders), were excluded in our calculation. Based on the results obtained from 16 cells, the average vesicle content was $1.36 \pm 0.53$ amol (mean \pm SD), equivalent to $818,000 \pm 319,000$ molecules of dopamine. $B$. Frequency versus the cubed root of attomoles of dopamine released ( 16 cells and 18,456 events).

body for $30 \mathrm{sec}$ following a $6 \mathrm{sec}$ stimulation with elevated potassium (Fig. 4). The only significant material detected following release had an electrophoretic mobility of $2.34 \times 10^{-4}$ $\mathrm{cm}^{2} / \mathrm{V} \cdot \mathrm{sec}$, which is identical to that of dopamine. The peak at $11.2 \mathrm{~min}$ was due to an electroactive neutral species that is also observed in the snail Ringer. As the capillary tip opening was 20 to 30 micrometers wide, this technique allows us to sample release primarily from the single cell body in question.

\section{Dopamine release is calcium dependent}

Release of neurotransmitter requires calcium influx into the cell to initiate the exocytotic machinery in the cell (Katz and Miledi, 1967; Llinás and Nicholson, 1975). The calcium dependence of the electrochemical response at a stimulated Planorbis dopamine cell has been examined in a calcium-free medium by sequentially stimulating the cell with elevated potassium containing calcium and not containing calcium (Fig. 5A). Clearly, without a source of extracellular calcium, exocytosis of dopamine does not occur in this system. Finally, the calcium transporting substance, ionomycin, has been used to stimulate the dopamine cell (Fig. $5 B$ ).

\section{Discussion}

The data presented here is the first example of a dynamic chemical measurement of calcium-dependent neurotransmittcr rclcasc from individual exocytotic events at a neuron. More importantly, however, this release is observed at the cell body of an intact neuron in vivo that has multiple synaptic connections on to other cells. It is not clear whether the released catecholamine is acting as a transmitter, a modulator, or a hormone. One might speculate that released dopamine is acting on a broad set of closely spaced neurons or other cclls near the cell body. It has recently been suggested that most dopamine released from synaptic terminals in vivo escapes the synapse and acts on surrounding terminals (Garris et al., 1994). Another possibility is that the released dopamine is acting as a trophic agent to guide neuronal growth cones during development. Recent evidence that acetylcholine acts as a trophic agent for directional growth of developing neurons in culture (Zheng et al., 1994) is consistent with this hypothesis. The neurons examined here were not developing, but rather in an adult Planorbis; however, the primitive neurons in an invertebrate might not possess the sophisticated cell machinery required to stop signaling after development.

It is important to determine if the exocytosis observed in these experiments is from the cell body or from other cell sources. Two alternative possibilities exist. Exocytosis could be observed from small glial cells known to be located around the dopamine neuron of Planorbis (Pentreath et al., 1974) or it could be observed from dopamine terminals of other neurons connected to the Planorbis dopamine cell body. To test these alternatives, we have stimulated the dopamine cell intracellularly with sodium and have observed similar exocytotic events (Fig. 3A) to those ohserved hy extracellular stimulation with potassium. In addition, we have also observed depolarization of the membrane potential of the dopamine cell during extracellular stimulation with potassium as measured by intracellular recording. This makes it unlikely that the release observed is from glial cells. 
A

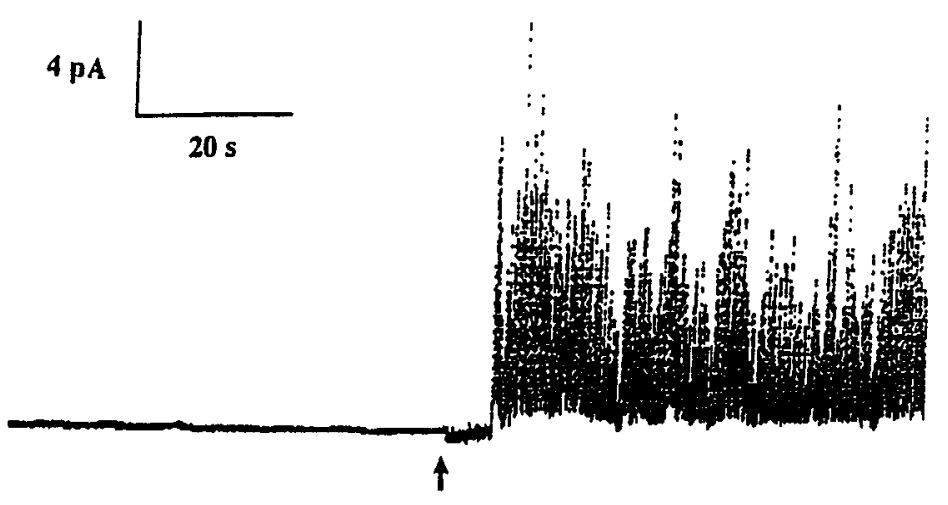

Figure 3. Dopamine current transients and background-subtracted voltammograms obtained by intracellular sodium stimulation and dopamine reverse transport. $A$, Current transients obtained from intracellular sodium stimulation. A glass pipette (about 1 $\mu \mathrm{m}$ in diameter) filled with $46 \mathrm{~mm}$ sodium chloride was placed inside a large dopamine cell of Planorbis. About 30 $\mathrm{pL}$ of the sodium chloride solution was injected during the amperometric measurement. $B$, The voltammogram obtained from the response recorded from another cell in an intracellular sodium chloride stimulation experiment. Stimulation conditions were the same as described in $A$. Twenty-five averaged voltammograms (obtained prior to stimulation) were background subtracted from 53 averaged voltammograms where significant release was observed. $C$, A voltammogram obtained from reverse transport of dopamine across the plasma membrane of the same cell as in $B$. A glass pipette (about $1 \mu \mathrm{m}$ in diameter) filled with $10 \mathrm{~mm}$ dopamine was used to inject dopamine into the cell. A sharp peak that corresponded to dopamine reverse transport (Sulzer et al. 1995) was observed after dopamine injection (data not shown). Fifteen averaged background voltammograms were subtracted from 5 averaged voltammograms at the top of the dopamine reverse transport peak. The same carbon fiber electrode $(11 \mu \mathrm{m}$ in diameter $)$ was used for both recordings.

The possibility that the exocytosis observed is from terminals that synapse onto the dopamine cell is considered remote for the following reasons. First, intracellular sodium stimulation should not directly elicit exocytosis from external terminals. Second, fluorescence and spectrophotofluorimetric measurements have shown no other dopamine neurons in this system. Third, release from synapses is not expected to provide current transients with 2 to $4 \mathrm{msec}$ rise times as exocytotic events inside the synaptic cleft would be removed from the electrode surface. Release from a synapse is expected to result in radial diffusion of the catecholamine out of the perimeter of the synapse. As active zones are typically micrometers across, the diffusion time would be hundreds of milliseconds to seconds in time. This has been modelled for multiple synapses in rat nucleus accumbens (Garris et al., 1994).

The time scale of individual events is in the range expected for exocytosis with 2 to $4 \mathrm{msec}$ rise time and $14 \mathrm{msec}$ basewidth. It is important to note that to maintain an acceptable signal-tonoise ratio, the data have been filtered with a two-pole low-pass filter having a roll off frequency of $100 \mathrm{~Hz}$ (Schroeder et al., 1992). Thus, peak widths less than $10 \mathrm{msec}$ are likely to be slightly broadened. Filtering at higher frequencies makes it difficult to discriminate smaller events from the noise, so a tradeoff is present for quantitating all events. The 2 to $4 \mathrm{msec}$ rise times must be thought of as an upper limit for the release events as the filtering and data acquision rates limit the response time to measurements in this range. Experiments are currently underway to increase the frequency of the time constant used while attempting to prevent loss of the smaller events.

The hursting pattern of exocytosis appears to indicate that the release of dopamine is, in fact, not a low-occurrence phenomenon. Bursting patterns in neuronal firing have been shown to be 
Figure 4. Capillary electrophoresis sampling and separation of released material following stimulation. Inset, A schematic representation of the stimulation and electrophoretic sampling of exocytosis at the giant dopamine cell. A brief pulse $(6 \mathrm{sec})$ from the stimulation pipette $(1 \mathrm{M} \mathrm{KCl}, 20 \mu \mathrm{m}$ from the cell body) was used to elicit exocytosis. An etched electrophoresis capillary was used to sample a $30 \mathrm{sec}$ plug of material by electroosmosis. $A$, The electrophoretic separation of material sampled from the dopamine neuron as described above. The peak at $6.8 \mathrm{~min}$ has an electrophoretic mobility corresponding to dopamine. The large peak at $11.2 \mathrm{~min}$ is representative of an electroactive neutral species also found in the snail Ringer. $B$, A capillary electrophoresis separation obtained from a solution of standard reagents immediately following the electropherogram shown in $A$. The numbers in parenthesis indicate the concentration of the analyte solution and amount of material injected based on electroosmotic flow: [A] Dopanine ( $32 \mu \mathrm{M}, 9.0$ fmol), [B] catechol $(41 \mu \mathrm{M}, 6.8 \mathrm{fmol})$, [C] uric acid $(90 \mu \mathrm{M}, 7.9 \mathrm{fmol}),[\mathrm{D}]$ DOPAC $(51$ $\mu \mathrm{M}, 3.3 \mathrm{fmol}$ ). The volume injected was $0.1 \mathrm{nl}$. The separation capillary for both electropherograms was $85.5 \mathrm{~cm}$ long.

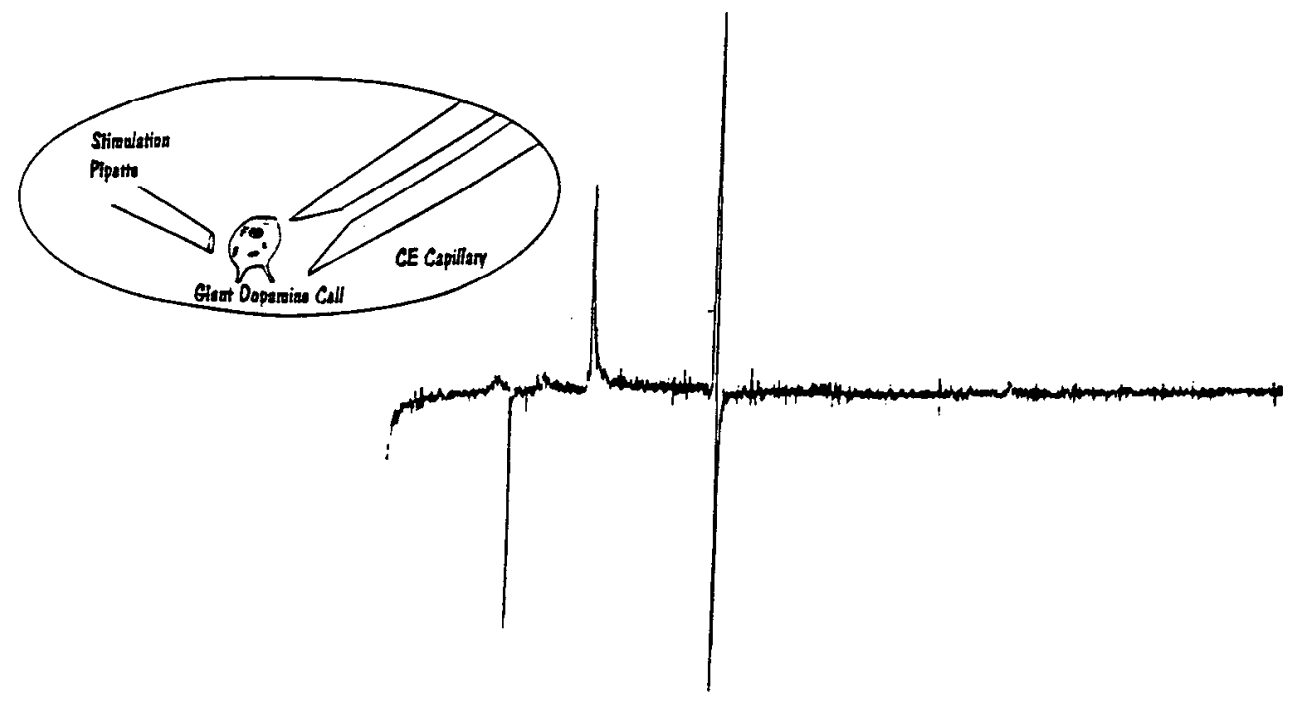

B

B

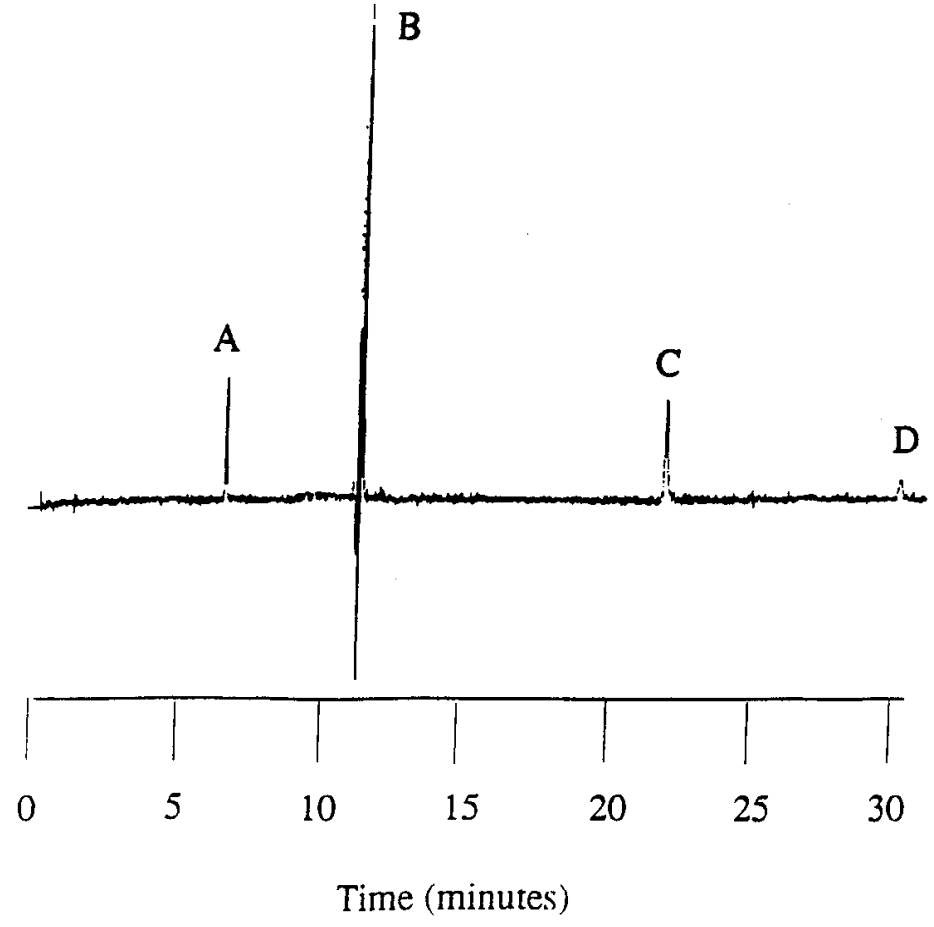

indicative of intracellular calcium fluctuations on longer time scales than the bursting pattern shown here (Randriamampita and Tsien, 1993; Tse et al., 1993). However, it is quite possible that fluctuations in intracellular calcium occur during stimulation of the dopamine cell in Planorbis. The use of ionomycin to stimulate the cell body effectively demonstrates that changes in intracellular calcium are required for the observed exocytosis of dopamine. Another possibility is that the bursting pattern observed in our data correlates to the individual action potentials or membrane potential oscillations that have been observed to lake place with a pacemaker-like manner or bursting firing pattern for molluscan cells and mammalian cells (Lichtensteiger et al., 1979; Arshavsky et al., 1988; Marcus and Carew, 1991; Jagadeesh et al., 1992; Kukuljan, 1992; Cardozo, 1993). This behavior is likely to result from interactions between the intact neuron and other neurons in this, system, clearly indicating the difference between these experiments in an intact neuron of Planorbis versus all previous exocytosis measurements by electrochemistry that have been carried out on hormonal cells in culture.

Our results show that exocytosis of a neurotransmitter can occur from the cell body of a processed neuron. For the system examined, the calcium dependence of release, voltammetric and electrophoretic identifications of the neurotransmitter, time course of individual release events, and the quantitative analysis of relcasc cvents collectively and convincingly demonstrate that neurotransmitter exocytosis occurs following cellular stimulation. Interestingly, this cell does not appear to possess autoreceptors on the cell body. In contrast to experiments monitoring exocytosis at adrenal cells where autoreceptors appear to limit 
A
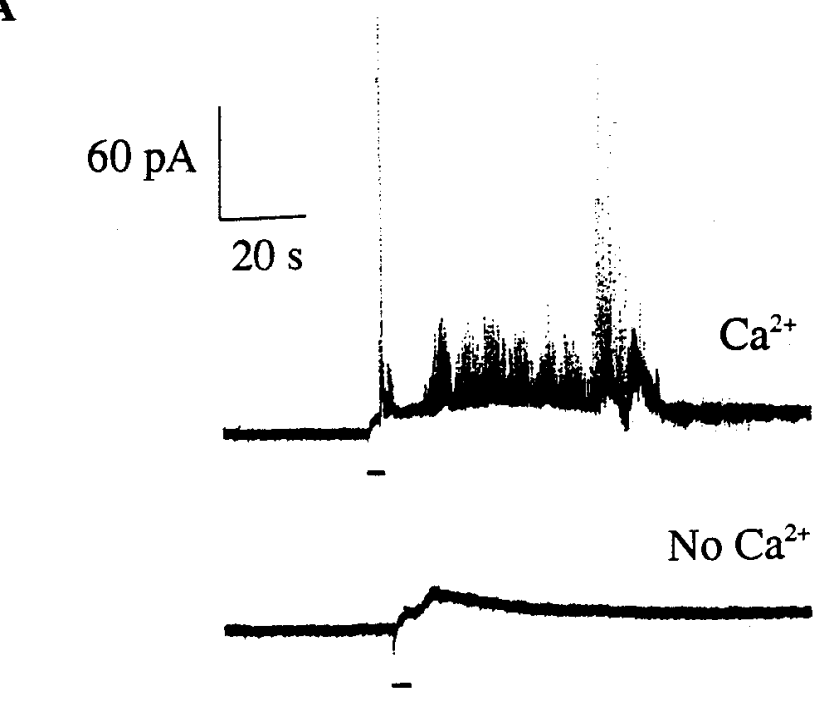

B the number of quantal cvents following a single stimulation (Zhou et al., 1994), the Planorbis cell often releases thousands of vesicles following a stimulation. In one case, 89,000 exocytotic events were monitored from a single stimulation of a cell by intracellular sodium injection $(40 \mathrm{pL})$ recorded over $130 \mathrm{~min}$. The dopamine cell of Planorbis has been estimated to contain approximately $5.4 \pm 0.6$ picomoles of dopamine (Powell and Cottrell, 1974), and has been shown to contain both light and dense core vesicles (Berry et al., 1974; Pentreath et al., 1974; Pentreath and Berry, 1975; Berry and Pentreath, 1978). As the average vesicle contains 1.36 attomoles of transmitter, there should be approximately $4 \times 10^{6}$ vesicles in the cell. This release represents approximately $2 \%$ of the total vesicles in the cell.

In addition to the large number of vesicles released from this cell body, the amount of catecholamine released from these vesicles varies with a very interesting distribution. The histogram of events versus the vesicle content shown in Figure $2 A$ shows a bimodal distribution, and each phase appears to drop off exponentially with fewer release events that result in larger amounts of catecholamine exocytosis. To explore this distribution more carefully, the histogram was plotted with the cubed root of vesicle content on the $\mathrm{x}$-axis to correlate release events with the average radius of vesicles (Fig. $2 B$ ). This plot clearly shows the bimodal distribution as two distinct Gaussians. It certainly appears that there are at least two distinct classes of vesicles or release events occurring at this cell. The smaller Gaussian has an average vesicle size considerably smaller (4\%) than that of the dominant gaussian and only makes up $9 \%$ of the total release events. Although two compartments of vesicles have been postulated for this cell before (Kristensen et al., 1994), it has been assumed that these compartments represented releasable versus reserve stores of dopamine (Besson et al., 1969). The classes of vesicles observed here are both releasable. These might represent dense versus light cored vesicles; however, many possibilities need to be explored here. This might be important in understanding the rationale for neurotransmitter exocytosis from the cell body of this neuron.

Further study should suggest the rationale for neurotransmitter exocytosis from the neuronal cell body. Nonexocytotic release of neurotransmitter has becn observed from the cytoplasm of neuronal cell bodies (Johnson and Pilar, 1980; Suetake et al., 1981) and from the somatodendritic region of mammals (Cheramy et al., 1981; Gauchy et al., 1987; Klitenick et al., 1992), although somatic-dendritic release can be partially inhibited by blockade of voltage-dependent calcium and sodium channels. In addition, exocytosis of the hormones vasopressin and oxytocin from cell bodies of the hypothalamic neurons has been shown by a combination of immunocytochemistry and electron microscopy (Pow and Morris, 1989). Dynarnic exucylotic release of neurotransmitter from the cell body of a processed neuron has not yet been observed. Taken together with recent observations that glial cells can signal nearby neurons (Nedergaard, 1994; Parpura et al., 1994), and that most dopamine released in the rat nucleus accumbens escapes the synapse (Garris et al., 1994), the massive exocytotic release of neurotransmitter from the neuronal cell body shown here suggests a radically different wiring of the brain from the classical synaptic view. We are currently conducting experiments to assess the generalizability of exocytosis from cell bodies on chemical neurotransmission in the brain.
Figure 5. Calcium-dependent release of dopamine from the cell body of the Planorbis dopamine cell. $A$, Amperometric recordings obtained from the same cell in a calcium-free medium by sequentially stimulating the cell with $1 \mathrm{M}$ potassium chloride containing $50 \mathrm{~mm}$ calcium chloride (top), 1 $\mathrm{M}$ potassium chloride alone (middle), and $1 \mathrm{M}$ potassium chloride containing $50 \mathrm{~mm}$ calcium chloride (bottom). In all three cases, equal length injections (4 sec), shown by the horizontal bars below the traces, were used. $B$, Current transients evoked by application of the calcium ionophore, ionomycin. In this experiment, about $270 \mathrm{nl}$ of $200 \mu \mathrm{M}$ ionomycin prepared in the snail Ringer solution was used in a $6 \mathrm{sec}$ pressure pulse (the horizontal bar) to the Planorbis dopamine cell that was prepared in normal snail Ringer solution. The same anount of ionomycin did not elicit dopamine exocytosis when the cell was in a calcium-free EGTA (1 mM) containing medium (data not shown). 


\section{References}

Alvarez de Toledo G, Fernández-Chacón R, Fernández JM (1993) Release of secretory products during transient vesicle fusion. Nature 363:554-558.

Arshavsky YuI, Deliagina TG, Orlovsky GN, Panchin YuV (1988) Control of feeding movements in the freshwater snail Planorbis corneus-II. Activity of isolated neurons of buccal ganglia. Exp Brain Res 70:323-331.

Berry MS (1972) A system of electrically coupled small cells in the buccal ganglia of the pond snail Planorbis corneus. J Exp Biol 56: 621-637

Bèrry MS, Cottrell GA (1973) Dopamine: excitatory and inhibitory transmission from a giant dopamine neuron. Nature New Biol 242: 250-253.

Berry MS, Cottrell GA (1975) Excitatory, inhibitory and biphasic synaptic potentials mediated by an identified dopamine-containing neuron. J Physiol (Lond) 244:589-612.

Berry MS, Cottrell GA (1979) Ionic basis of different synaptic potentials mediated by an identified dopamine-containing neuron in Planorbis. Proc R Soc Lond [Biol] 203:427-444.

Berry MS, Pentreath VW (1978) The characterized dopamine neuron in Planorbis corneus. In: Biochennistry in characterized neurons (Osborne N, ed), pp 81-115. Oxford: Pergamon.

Berry MS, Pentreath VW, Turner JD, Cottrell GA (1974) Effects of 6-hydroxydopamine on an identified dopamine-containing neuron in the central nervous system of Planorbis corneus. Brain Res 76:309_ 324

Besson MJ, Cheramy A, Feltz P, Glowinski J (1969) Release of newly synthesized dopamine from dopamine-containing terminals in the striatum of the rat. Proc Natl Acad Sci USA 62:741-748.

Cardozo DL (1993) Midbrain dopaminergic neurons from postnatal rat in long-term primary culture. Neuroscience 56:409-421.

Charles AC, Merrill JE, Dirksen ER, Sanderson MJ (1991) Intercellular signaling in glial cells: calcium waves and oscillations in response to mechanical stimulation and glutamate. Neuron 6:983-992.

Chen TK, Luo G, Ewing AG (1994) Amperometric monitoring of stimulated catecholamine release from rat pheochromocytoma (PC12) cells at the zeptomole level. Anal Chem 66:3031-3035.

Cheramy A, Leviel V, Glowinski J (1981) Dendritic release of dopamine in the substantia nigra. Nature 289:537-542.

Chien JB, Saraceno RA, Ewing AG (1988) Intracellular voltammetry with ultrasmall carbon ring electrodes. In: Redox chemistry and interfacial behavior of biological molecules (Dryhurst G, Niki K, eds), pp 417-424. New York: Plenum.

Chow RH, von Rüden L, Neher E (1992) Delay in vesicle fusion revealed by electrochemical monitoring of single secretory events in adrenal chromaffin cells. Nature 356:60-63.

Coupland RE (1968) Determining sizes and distribution of sizes of spherical bodies such as chromaffin granules in tissue sections. $\mathrm{Na}-$ ture 217:384-388

Garris PA, Ciolkowski EL, Pastore P, Wightman RM (1994) Efflux of dopamine from the synaptic cleft in the nucleus accumbenss of the rat brain. J Neurosci 14:6084-6093.

Gauchy C, Kemel ML, Desban M, Romo R, Glowinski J, Besson MJ (1987) The role of dopanine released from distal and proximal dendrities of nigrostriatal dopaminergic neurons in the control of GABA transmission in the thalamic nucleus ventralis medialis in the cat. Neuroscience 22:935-946.

Heuser JE, Reese TS (1977) Structure of the synapse. In: Handbook of physiology, Vol 1, The nervous system (Kandel ER, ed), pp 261294. Bethesda, MD: American Physiological Society.

Jagadeesh B, Gary CM, Ferster D (1992) Visually evoked oscillations of membrane potential in cells of cat visual cortex. Science 257:552 554

Johnson DA, Pilar G (1980) The release of acetylcholine from postganglionic cell bodies in response to depolarization. J Physiol (Lond) 299:605-619.

Katz B, Miledi R (1967) The timing of calcium action during neuromuscular transmission. J Physiol (Lond) 189:535-544.

Kelly RS, Wightman RM (1986) Bevelled carbon fiber ultramicroelectrodes. Anal Chim Acta 187:79-87.

Kennedy RT, Huang L, Atkinson MA, Dush P (1993) Amperometric monitoring of chemical secretions from individual pancreatic b-cells. Anal Chem 65:1882-1887.

Klitenick MA, DeWitte P, Kalivas PW (1992) Regulation of somato- dendritic dopamine release in the ventral tegmental area by opioids and GABA: an in vivo microdialysis study. J Neurosei 12:2623-2632.

Kristensen HK, Lau YY, Ewing AG (1994) Capillary electrophoresis of single cells: observation of two compartments of neurotransmitter vesicles. J Neurosci Methods 51:183-188.

Kukuljan M, Stojilkovi SS, Rojas E, Catt KJ (1992) Apamine-sensitive potassium channels mediate agonist-induced oscillations of membrane potential in pituitary gonadotrophs. FEBS Lett 301:19-22.

Leszczyszyn DJ, Jankowski JA, Viveros OH, Dilibertu EJ Ji; Near JA, Wightman RM (1990) Nicotinic receptor-mediated catecholamine secretion from individual chromaffin cells. J Biol Chem 265:1473614737.

Lichtensteiger W, Felix D, Hefti F (1979) Spike activity and histofluorescence correlated in the giant dopamine neuron of Planorbis corneus. Brain Res 170:231-245.

Llinás R, Nicholson C (1975) Calcium role in depolarization-secretion coupling: an aequorin study in the squid giant synapse. Proc Nat Acad Sci USA 72:187-190.

Logan SD, Cottrell GA (1975) Responses of an identified dopaminecontaining neuron to tontophoretically applied drugs. Neuropharmacology 14:453-455.

Loker JE, Walker RJ, Kerkut GA (1975) An electrophysiological, pharmacological and fluorescent study on six identified neurons from the brain of Planorbis corneus. Comp Biochem Physiol 51C:83-89.

Marcus EA, Carew TJ (1991) Development and modulation of endogenous bursting in identified neuron R15 of jevenile Aplysia. J Neurobiol 22:418-429.

MacDonald JF, Berry MS (1978) Further identification of multiple responses mediated by dopamine in the CNS of Planorbis corneus. Can J Physiol Pharmacol 56:7-18.

Marsden C, Kerkut GA (1970) The occurrence of monoamines in Planorbis corneus: a fluorescence microscopic and microspectrometric study. Comp Gen Pharmacol 1:101-116.

Mennerick S, Zorumski CF (1994) Glial contributions to excitatory neurotransmission in cultured hippocampal cells. Nature 368:59-62.

Mesaros JM, Ewing AG, Gavin PF (1994) Electrochemical detection in microcolumn separations. Anal Chem 66:527A-537A.

Murphy TH, Blatter LA, Wier WG, Barbaban JM (1993) Rapid communication between neurons and astrocytes in primany cortical cultures. J Neurosci 13:2672-2679.

Nedergaard M (1994) Direct signaling from astrocytes to neurons in cultures of mammalian brain cells. Science 263:1768-1771.

Osborne NN, Priggemeier E, Neuhoff V (1975) Dopamine metabolism in characterized neurons of Planorbis corneus. Brain Res 90:261271

Parpura V, Basarsky TA, Liu F, Jeftinija K, Jeftinija S, Haydon PG (1994) Glutamate-mediated astrocyte-neuron signalling. Nature 369 744-747.

Pentreath VW, Berry MS (1975) Nerve ending specializations in the central ganglia of Planorbis corneus. Cell Tissue Res 163:111-124.

Pentreath VW, Berry MS, Cottrell GA (1974) Anatomy of the giant dopamine-containing neuron in the left pedal ganglion of Planorbis corneus. Cell Tissue Res 151:369-384.

Pow DV, Morris JF (1989) Dentrites of hypothalamic magnocellular neurons release neurohypophysial peptides by exocytosis. Neurosci ence 32:435-439.

Powell B, Cottrell GA (1974) Dopamine in an identified neuron of Planorbis corneus. J Neurochem 22:605-606.

Randriamampita C, Tsien RY (1993) Emptying of intracellular $\mathrm{Ca}^{2+}$ stores releases a novel small messenger that stimulates $\mathrm{Ca}^{2+}$ influx. Nature 364:809-814.

Redman S (1990) Quantal analysis of synaptic potentials in neurons of the central nervous system. Physiol Rev 70:165-198

Schroeder TJ, Jankowski JA, Kawagoe KT, Wightman RM, Lefrou C, Amatore C (1992) Analysis of diffusional broadening of vesicular packets of catecholamines released from biological cells during exocytosis. Anal Chem 64:3077-3083.

Schroeder TJ, Jankowski JA, Senyshyn J, Holz RW, Wightman RM (1994) Zones of exocytotic release on bovine adrenal medullary cells in culture. J Biol Chem 269:17215-17220.

Sloss S, Ewing AG (1993) Improved method for end-column amperometric detection for capillary electrophoresis. Anal Chem 65:577581.

Steiner FA, Felix D (1989) Effects of hypothalamic releasing hormones and biogenic amines on identified neurons in the circumoesophageal 
ganglia of the water snail Planorbis corneus. Comp Biochem Physiol 92C:301-307.

Suetake K, Kojima H, Inanaga K, Kotetsu K (1981) Catecholamine is released from non-synaptic cell-soma membrane: histochemical evidence in bullfrog sympathetic ganglion cells. Brain Res 205:436-440.

Sulzer D, Chen TK, Lau YY, Kristensen H, Rayport S, Ewing A (1995) Amphetamine redistributes dopamine from synaptic vesicles to the cytosol and promotes reverse transport. J Neurosci 15:4102-4108.

Tse A, Tse FW, Almers W, Hille B (1993) Rhythmic exocytosis stimulated by $\mathrm{GnRH}$-induced calcium oscillations in rat gonadotropes Science 260:82-84.
Wightman RM, Jankowski JA, Kennedy RT, Kawagoe KT, Schroeder TJ, Leszczyszyn DJ, Near JA, Diliberto EJ Jr, Viveros OH (1991) Temporally resolved catecholamine spikes correspond to single vesicle release from individual chromaffin cells. Proc Natl $\Lambda$ cad $\mathrm{Sci}$ USA 88:10754-10758.

Zheng JQ, Felder M, Connor JA, Poo M (1994) Turning of nerve growth cones induced by neurotransmitters. Nature 368:140-144.

Zhou R, Luo G, Ewing AG (1994) Direct observation of the effect of autoreceptors on stimulated release of catecholamines from adrenal cells. J Neurosci 14:2402-2407. 